\title{
The Effect of Oxytocin Massage on the Fundal Height of Multiparous Mother on the First until Tenth Day of Postpartum
}

\author{
Mayasari Putri Ardela ${ }^{1}$, Nara \\ Lintan Mega Puspita ${ }^{2}$, Lindha \\ Sri Kusumawati ${ }^{1}$, Sunaningsih ${ }^{2}$ \\ ${ }^{1}$ Midwifery Proffesion Program \\ Kadiri University, Indonesia \\ ${ }^{2}$ Bachelor of Midwifery Program \\ Kadiri University, Indonesia \\ Email: \\ mayasari.ardela@unik-kediri.ac.id
}

Received: October 5, 2020

Accepted : November 29, 2020

Published : November 30, 2020

\begin{abstract}
The Maternal Mortality Ratio (MMR) is still far from the target of Sustainable Development Goals (SDGs) which is 70 per 100,000 live births in 2030. Nationally, the main cause of maternal death is due to bleeding. One effort to prevent the occurrence of postpartum hemorrhagic is oxytocin massage. This massage can stimulate the oxytocin hormone so that the uterine involution process can run normally. This research aims to determine the effectiveness of the massage of oxytocin on the acceleration of uterine involution on the multiparous mother since the first day until the tenth day of postpartum. The design of this research is the quasi-experiment with a post-test with the control group on 20 persons that are determined by purposive sampling. The research samples were divided into 2 groups, i.e. 10 people were given a massage of oxytocin and 10 people were not massaged. The results showed a significant reduction in fundal height (One-Way Anova $\mathrm{p}$ $<0.05$ ) with an average declining more than $1 \mathrm{~cm}$. From the results of this study, it can be concluded that the massage of oxytocin can accelerate the high decline of uterus fundus.
\end{abstract}

Keywords: oxytocin massage, multiparous, fundal height

Copyright @ 2020 IIK STRADA Indonesia All right reserved.

\section{(c) (†) (9)}

This is an open-acces article distributed under the terms of the Creative Commons Attribution-ShareAlike 4.0 International License.

\section{INTRODUCTION}

Maternal Mortality Ratio (MMR) is an indicator to see the degree of women's health and become one of the components of the development index and quality of life Index (Sumarmi, 2017). Up to 2019, the Maternal Mortality Ratio (MMR) in Indonesia remains high, which is 305 per 100,000 live births. Whereas, Maternal Mortality Ratio (MMR) was targeted down from 102 per 100,000 live births in 2015 following the fifth goal of the Millennium Development Goals (MDGs). In the Sustainable Development Goals (SDGs), Maternal Mortality Ratio (MMR) target is 70 per 100,000 live births in 2030.

Nationally, the highest Maternal Mortality Ratio (MMR) cause is bleeding. One factor of predisposition is the subinvolution of the uterus due to uterine muscular weakness in the postpartum multiparous mother. Symptoms of subinvolution of the uterus include a decrease in the slow uterine involution, the tonus of flabby, and no uterine contractions in the postpartum mother resulting bleeding (Marmi, 2014). Involution is a process by which the uterus returns to the condition before pregnancy. This process begins as soon as the placenta is born due to the contraction of the smooth 
muscles of the uterus and the retraction of the uterine muscular fibers that occur continuously. In case of failure in this process, it will cause subinvolution (Cunningham et al., 2013).

Efforts to prevent bleeding can be done since childbirth stages 3 and 4 with the administration of oxytocin which plays a role in the process of uterine involution. One way to control the bleeding that comes from the place of placental implantation by correcting the contraction and retraction of the strong myometrium fibers is with the massage of oxytocin. Efforts to maintain a uterine contraction through massage are useful to stimulate the secretion of oxytocin hormones so it is an important part of the treatment of postpartum mothers (Bobak et al., 2005). Treatment of repeated massage can increase the production of oxytocin hormones whose reaction can be felt 6-12 hours after the massage (Anggraini \& Rajiani, 2018).

Based on preliminary survey results, oxytocin massage has not been done at primary health care facilities in Tulungagung. The community remains lack of information about the benefits of oxytocin massage. Therefore, the high-decline acceleration efforts of the fundal height with the oxytocin massage are expected to prevent the postpartum bleeding due to uterine subinvolution. The study aims to determine the effectiveness of oxytocin massage on the acceleration of the high decline of fundal height on the multiparous mother since the first day until the tenth day of postpartum.

\section{MATERIALS AND METHODS \\ Design and Samples}

Research is conducted in PMB Evita Dwi Retno, Tulungagung, East Java in January-February 2020. The research design used in this research is a quasi-experiment with the form of a post-test with the control group. The sampling technique is taken by using purposive sampling with a total of 20 mothers of postpartum multipara. They are divided into 2 groups, 10 mothers are massaged oxytocin and 10 mothers are not massaged oxytocin.

\section{Data Collection}

The chosen respondent is a multiparous pregnant woman who performs antenatal care in the thirdtrimester pregnancy with an estimate of childbirth from 13 January to 13 February 2020 which has been following the criteria of inclusion. Researchers performed oxytocin massage on the treatment group from the first day to the tenth day of postpartum. Observation of uterine involution is carried out by measuring the fundal height in the experimental group after having oxytocin and control group which is not a massaged.

\section{Data Analysis}

Test of data normality uses Kolmogorov-Smirnov and test of hypotheses uses One-Way Anova. All tests are done by using SPSS for Windows 24.

\section{RESULTS}

Based on the result of One Way Anova, it shows that there is a meaningful difference ( $\mathrm{P}$ value $0.000<\propto)$ on the high average fundal height which is observed from the first day until the tenth day of the postpartum mother who is massaged with oxytocin (treatment) and not massaged (control).

Table 1. The Result of Difference Test on Control Group and Experimental Group with Oxytocin Massage

\begin{tabular}{ccc} 
& \multicolumn{2}{c}{ Mean \pm SD } \\
\cline { 2 - 3 } Observation & Control Group & $\begin{array}{c}\text { Experimental Group with } \\
\text { Oxytocin Massage }\end{array}$ \\
Day-1 & $1.57 \pm 0.33^{\mathrm{a}}$ & $2.53 \pm 0.53^{\mathrm{a}}$ \\
Day-2 & $3.35 \pm 0.42^{\mathrm{b}}$ & $4.18 \pm 0.23^{\mathrm{b}}$ \\
Day-3 & $4.47 \pm 0.34^{\mathrm{c}}$ & $5.06 \pm 0.25^{\mathrm{c}}$ \\
Day-4 & $4.90 \pm 0.22^{\mathrm{cd}}$ & $5.63 \pm 0.38^{\mathrm{d}}$ \\
Day-5 & $5.34 \pm 0.27^{\mathrm{de}}$ & $6.32 \pm 0.38^{\mathrm{e}}$ \\
Day-6 & $5.82 \pm 0.25^{\mathrm{e}}$ & $6.94 \pm 0.36^{\mathrm{f}}$ \\
Day-7 & $6.56 \pm 0.47^{\mathrm{f}}$ & $7.59 \pm 0.34^{\mathrm{g}}$ \\
Day-8 & $7.16 \pm 0.49^{\mathrm{g}}$ & $8.20 \pm 0.23^{\mathrm{h}}$ \\
Day-9 & $7.84 \pm 0.48^{\mathrm{h}}$ & $8.88 \pm 0.20^{\mathrm{i}}$
\end{tabular}




\begin{tabular}{ccc} 
Day-10 & $8.63 \pm 0.63^{\mathrm{i}}$ & $9.66 \pm 0.30^{\mathrm{j}}$ \\
p-value & 0.000 & 0.000 \\
(One Way Anova) & & \\
\hline
\end{tabular}

On an average of \pm SD if having a different letter, it means there is a meaningful difference (the pvalue of $<0.05$ ), and if having the same letter, it means there is no meaningful difference.

Table 1, explains that the overall average of fundal height since the first day until the tenthday observation of postpartum multiparous mother showed a daily significant decline, both in the group which is not massaged (control) and massage group of oxytocin (experiment). When it is based on the average value, the decline of fundal height in the control group reaches $1 \mathrm{~cm}$ on average with the lowest average fundal height at the time of the tenth-day observation of $8.62 \mathrm{~cm}$. While in the treatment group, the decline of fundal height reaches more than $1 \mathrm{~cm}$ with the lowest average fundal height at the time of the tenth-day observation of $9.65 \mathrm{~cm}$.

\section{DISCUSSION}

The oxytocin massage is a spinal massage ranging from Costa 5-6 through scapula. This massage can accelerate the work of the parasympathetic nerve to produce the oxytocin hormone (Vidayanti, 2014). Oxytocin hormones are useful for strengthening and regulating uterine contractions, compressing blood vessels, as well as helping hemostatic so that it reduces the risk of uterus atony. A strong uterine contraction will optimize the process of uterine involution so that it will be able to prevent the occurrence of postpartum bleeding (Cunningham et al., 2013). From the result of this study, it shows that the massage of oxytocin is effective towards the acceleration of the fundal height in the mother of multiparous from the first day until the tenth day postpartum with a decrease of fundal height. It reaches more than $1 \mathrm{~cm}$ with the lowest average of fundal height at $9.658 \mathrm{~cm}$ of the time of the tenth-day observation. The physiological effect of the massage of oxytocin is stimulating the anterior and posterior pituitary to secrete the hormone oxytocin thereby stimulating the smooth muscle contractions of the uterus that affect the acceleration of the uterine involution process. The presence of oxytocin reflects is characterized by the pain due to uterine contractions (Sulistyawati, 2009).

The research conducted by Wada (2014) shows a similar result. Postpartum mothers having oxytocin massage undergo better involution uterus rather than the ones who do not have oxytocin massage. Generally, the involution of the uterus on the second day postpartum is $\geq 2$ fingers below the navel. So, by having of massage of oxytocin can strengthen and regulate uterine contractions well, so that the involution of the uterus can be better.

In the group that does not have oxytocin massage, the average decline of fundal height can reach $1 \mathrm{~cm}$ with the lowest average fundal height at 8.62 on the tenth day of the observation. The process of involution of the uterus in the control group occurs slower due to a slight stimulation of the oxytocin hormone so that the uterine contraction is not adequate and can cause subinvolution of the uterus that affects the number of lochea which increases and can risk the occurrence of bleeding (Prawirohardjo, 2014).

The uterine contraction happened due to intervention conducted by researchers in the form of oxytocin massage. It causes the reduction of fundal height in respondents with faster oxytocin decrease. While the respondents were not massaged, there was no decrease in the slow involution, but normally it can reach $1 \mathrm{~cm}$ on average per day. This result is following the theory that fundal height decreased $1 \mathrm{~cm}$ under the navel of each day post-natal (Manuaba et al. 2007). Gradually, the size of the uterus will become smaller (involution) until its' pre-pregnancy size. It is supported by research conducted by Khairani, et al. (2012) stating that the administration of oxytocin massage affects the involution of the uterus on postpartum mothers.

\section{CONCLUSION}

The result of this study proves that the massage of oxytocin can accelerate the high decline of the fundal height on the multiparous mother since the first day until the tenth day of postpartum. The physiological effects of the massage of oxytocin can stimulate the anterior and posterior pituitary to secrete oxytocin hormone so that it will stimulate the myometrium muscle contractions of the uterus 
that affect the acceleration of the uterine involution process and prevent the occurrence of postpartum bleeding.

\section{ACKNOWLEDGMENTS}

The author is thankful to respondents for their valuable information and their awareness to participate in this research.

\section{CONFLICTS OF INTEREST}

The author declares that they have no conflict of interest

\section{REFERENCES}

Anggraini, Y., \& Rajiani, I. (2018). The effect of oxytocin massage on changing of Symphysis-Fundal height (SFH) in post-normal and post caesarean birth delivery. Indian Journal of Public Health Research \& Development, 9(10), 153-157.

Bobak, I. M., Lowdermilk, D. L., Jensen, M. D., \& Perry, S. E. (2005). Buku ajar keperawatan maternitas. Jakarta: EGC.

Cunningham, F. G., Leveno, K. J., Bloom, S. L., Hauth, J. C., Gilstrap, L., \& Wenstrom, K. D. (2013). Obstetri Williams (Williams Obstetri). Jakarta: EGC.

Khairani, L. (2012). Pengaruh pijat oksitosin terhadap involusi uterus pada ibu post partum di ruang post partum kelas iii rshs bandung. Students e-Journal, 1(1), 33.

Manuaba, I. B. G., Manuaba, I. C., \& Manuaba, I. B. G. F. (2007). Pengantar kuliah obstetri. Jakarta: EGC, 450-55.

Marmi, S. (2014). Asuhan Kebidanan pada Masa Nifas 'Peuperium Care.'. Yogyakarta: Pustaka Pelajar.

Prawirohardjo, S. (2014). Ilmu Kebidanan Sarwono Prawirohardjo. Jakarta: PT Bina Pustaka Sarwono Prawiroharjo.

Sulistyawati, A. (2009). Buku ajar asuhan kebidanan pada ibu nifas. Yogyakarta: Andi Offset, 1-6.

Sumarmi, S. (2017). Model Sosio Ekologi Perilaku Kesehatan dan Pendekatan Continuum of Care untuk Menurunkan Angka Kematian Ibu. The Indonesian Journal of Public Health, 12(1): 129-141.

Vidayanti, V. (2014). Pengaruh Pijat Punggung Menggunakan Minyak Esensial Lavender Terhadap Produksi ASI Pasca Bedah Sesar di RSUD Panembahan Senopati Bantul (Doctoral dissertation, Yogyakarta: Universitas Gadjah Mada).

Wada, F. H. (2014). Pengaruh Pijat Oksitosin Terhadap Involusi Uterus Pada Ibu Postpartum Primigravida Di RSUD Panembahan Senopati Bantul Yogyakarta III RSHS. Thesis. Retrieved from http://thesis.umy.ac.id/datapublik/t34055.pdf 